Jurnal Biota Vol. 7 No. 2, 2021

64 | ISSN: 2460-7746 (online); ISSN: 2528-262X (print)

\title{
Seagrass Vegetation Analysis in Jhembengan and Pasir Putih Beach, Bawean Island, East Java
}

\author{
Muhammad Asmuni Hasyim*, Bahrul Ulum, Berry Fakhry Hanifa \\ Biology Program Study, Faculty of Science and Technology, Maulana Malik Ibrahim State Islamic \\ University of Malang \\ *email: asmunimuhammad@bio.uin-malang.ac.id
}

Article Info

Keyword:

Distribution

Cover

Lamun (Seagrass)

Article history:

Received: 25/01/2021

Revised: 28/06/2021

Accepted: 05/07/2021

\begin{abstract}
Seagrass is a flowering plant that lives in coastal areas In Indonesia there are 12 species, where seagrasses are able to live at a depth of 1-90 meters, seagrass growth is influenced by several factors including the intensity of sunlight. The purpose of this study was to observe the cover, distribution, Importance Value Index (IVI) and correlation of abiotic factors with seagrass in Jhembangan Beach and White Sand on Bawean Island, East Java. The quadratic transect with $50 \mathrm{~m}$ length was used. Each station equipped with 3 transects with a distance of $25 \mathrm{~m}$. The data collected includes the parameter of type, stand, and water quality. The data analyze use Past Program 3.15 systems. Three species of seagrass plant were collected. The total seagrass cover value was 32.6 percent at Jhembangan Beach, and 38 percent at Pasir Putih Beach. Clumped and uniform types were included in the distribution of seagrass at Jhembangan and Pasir Putih beach. The highest of important value index In Jhembangan and Pasir Putih was Thallasia hemprichii, while the association to abiotic factor such temperature, $\mathrm{pH}$, salinity and $D O$ variables are included in the good or perfect correlation with values range from 0.7 to 0.9 .
\end{abstract}

Copyright $@ 2021$ Author(s). All Right Reserved

\section{Introduction}

Seagrass is a marine plant that can be distinguished between roots, rhizomes and leaves. Seagrasses are able to live on sand, coral or mud substrates with a depth of 1-90 meters influenced by the intensity of sunlight. In Indonesia there are 12 species.

Seagrass is an angiosperm plant that reproduces sexually and vegetatively with roots, rhizomes, leaves, flowers, and fruit) (Menteri Negara Lingkungan Hidup, 2004). There are tremendous benefits to the presence of seagrass in coastal areas since seagrass plays an important role as a nutrient contributor to the fertility of the coastal and marine ecosystem which support the life of flora and fauna (Baransano \& Mangimbulude, 2011).

Various ecological benefits of seagrass are not matched by weak conditions of seagrass (fragile ecosystem). The nature of human and industrial activities heavily effect the ecosystem balance of the seagrass, and the contaminant of land and sea waste will harm the seagrass ecosystem (Nybakken \& Willard, 1992). According to Cabaço et al. (2008) industrial waste can make turbid seawater, thereby restricting the entry of sunlight into the water that is useful for the photosynthesis process. Similar study also shows that the seagrass cover in aquatic ecosystem of Pari Island has decreased by $25 \%$ (1999-2004) 
caused by growth of coastal areas of Pari Island (Sjafrie et al., 2018).

The research was conducted in Bawean Island's Jhembangan and Pasir Putih beaches. Both areas have different conditions in which Jhembangan Beach usually used as fishing boat resting place and located right next to the main road, while Pasir putih Beach located far from the local activities and have plenty of mangrove plants along the coast that serve as sediment barrier from the sea.

The purpose of this study was to observe the cover, distribution, Importance value Index (IVI) and correlation of abiotic factors with seagrass in Jhembangan Beach and White Sand on Bawean Island, East Java. The results of this research will later decide the state of the seagrass beds and the surrounding ecosystem, on the Jhembangan and Pasir Putih beach.

\section{Materials and Methods}

The research was conducted at Jhembangan Beach (5 ${ }^{\circ} 46 ' 52$ 'S $\left.112^{\circ} 36 ' 32^{\prime} \mathrm{E}\right)$ and Pasir Putih Beach (5 ${ }^{\circ} 46^{\prime} 3^{\prime} \mathrm{S} 112^{\circ} 37^{\prime} 8$ 'E) in November 2019. Bawean Island, Gresik Regency, East Java. The series of activities began with surveys, literature reviews, and field data collection. Identification of Seagrass was conducted in Laboratory of ecology, Biology Studi Program, Faculty of Science and Technology, Maulana Malik Ibrahim State Islamic University of Malang.

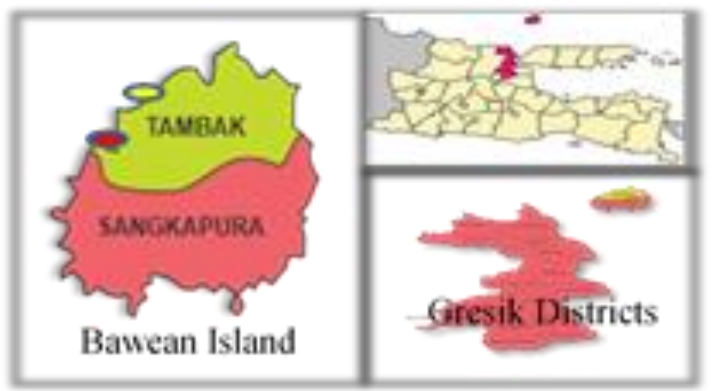

Figure 1 Research location (Google Earth)

O: Pasir Putih Beach : Jhembangan Beach

Standard equipment was used int this studies such GPS, camera, stationery, roll meter, plastic sample, identification book, 1x1 m map, $\mathrm{pH}$ meter, hand refractometer, aquades, tissue, snorkeling equipment.
The data was obtained using $50 \mathrm{~m}$ square line transect, where each transect consists of 10 of $1 \times 1 \mathrm{~m}$ plots with a $5 \mathrm{~m}$ distance between the plots to meet the minimum limit of 10 percent of the total area. There were 3 transects placed in each coast with a gap of $25 \mathrm{~m}$ between them (Menteri Negara Lingkungan Hidup, 2004).

\section{Data Analysis}

The data analyzed such: seagrass species composition, seagrass cover, distribution and Importance Value Index. Using the PAST 3.15 program for the association study of seagrass with abiotic factors. The formula used for each analysis of data are.

\section{Seagrass Cover}

$$
\mathrm{C}=\frac{\Sigma(M i x f i)}{\Sigma f}
$$

$\mathrm{C}$ : percentage of seagrass cover

Mi: percentage of midpoint of class presence of seagrass $i$

F : number of sub-plot the presence of seagrass (Menteri Negara Lingkungan Hidup, 2004).

\section{Seagrass Ditribution}

Information:

$$
\mathrm{Id}=n \frac{\Sigma \mathrm{X}^{2}-\mathrm{N}}{N(N-1)}
$$

Id : Morisita Index

$\mathrm{n}$ : number of sampling plots

$\mathrm{N}$ : total number of individuals in $\mathbf{n}$ plots

$\mathrm{X}$ : number of individuals on each plot

(Brower et al., 1998).

After obtaining the Id value for each type of seagrass, further testing is carried out through the calculation of $\mathrm{Mu}$ and $\mathrm{Mc}$ :

$$
\begin{aligned}
& \mathrm{Mu}=\frac{X^{2} 0,975-\mathrm{n}+\Sigma \mathrm{X}}{(\Sigma X)-1} \\
& \mathrm{Mc}=\frac{X^{2} 0,025-\mathrm{n}+\Sigma \mathrm{X}}{(\Sigma X)-1}
\end{aligned}
$$

Information:

$\mathrm{Mu} \quad$ : Morisita index for uniform distribution.

Mc : Morisita index for clumped distribution. 
After getting the value of $\mathrm{Mu}$ or $\mathrm{Mc}$, the standard degree of Morisita is searched with the formula.

Formula1. Ip $=0,5+0,5 \frac{I d-M c}{n-M c}$

Formula 2. $\mathrm{Ip}=0,5 \frac{I d-1}{M c-1}$

Formula 3. $\mathrm{Ip}=-0,5 \frac{I d-1}{M c-1}$

Formula 4. Ip $=-0,5+0,5 \frac{I d-M u}{M u}$

There are 4 formulas for calculating Ip, depending on the result value of Id and Mc / $\mathrm{Mu}$, as for determining the formula:

a. Formula 1 is used if Value Id $>1$, and Id $<$ Mc.

b. Formula 2 is used if Value Id $>1$, and Id $>\mathrm{Mc}$

c. Formula 3 is used if Value Id $<1$, and Id $>$ $\mathrm{Mu}$

d. Formula 3 is used if Value $\mathrm{Id}<1$, and $\mathrm{Id}<$ $\mathrm{Mu}$

The result then used to determine the distribution of seagrass species based on the Ip value obtained:

Ip Value $<0$, included as uniform distribution Ip Value $=0$, included as random distribution Ip Value $>0$, included as clumped distribution

\section{Importance Value Index (IVI)}

a. Density (Ki) (Fachrul, 2007):

Information:

$$
\mathrm{Ki}=\frac{n i}{A}
$$

$\mathrm{Ki} \quad$ : Density (number of Stands $/ 1 \mathrm{~m}^{2}$ )

ni : Number of Individual species -i

A : The area observation

b. Relative Density (KR) (Fachrul, 2007):

Information:

$$
\mathrm{KR}=\frac{n i}{\sum n} X 100
$$

KR : Relative Density

ni : number of Individual species -i

$\sum n:$ number of individuals of all types

c. Frequency type (F) (Fachrul, 2007):

Information:

$$
\mathrm{Fi}=\frac{\mathrm{Pi}}{\sum \mathrm{P}}
$$

Fi : Frequency type-i
Pi : Number of sample plots in which species -i were found

$\Sigma \mathrm{P} \quad$ : Total number of sample plots observed

d. Relative Frequency (FR) (Fachrul, 2007)

$$
\mathrm{FR}=\frac{F i}{\sum F} \mathrm{X} 100
$$

Information:

FR : Relative Frequency (\%)

$\mathrm{Fi}:$ Frequency type $-\mathrm{i}$

$\Sigma F \quad$ : Total frequencies for all types

e. Importance Value Index (Fachrul, 2007)

$$
\mathrm{INP}=\mathrm{FR}+\mathrm{KR}
$$

Information:

IVI : Importance Value Index

FR : Relative Frequency

KR : Relative Density

\section{Results and Discussion}

\section{Type of Seagrass Found}

The results found 3 species of seagrass in Pasir Putih they are: Enhalus acoroides, Halophila ovalis, and Thalassia hemripchii, while only Enhalus acoroides and Thalassia hemprichii found in Jhembangan beach. (Hernawan et al., 2017) notes that Thalassia hemprichii has a distinctive feature by having black spots on its leaves, the Enhalus acoroides is distinguished by its leaves exceeding 1 meter in length, and there is hair on the stemfor Halophila ovalis. (Sjafrie et al., 2018) states that the seagrass of Halophila ovalis has oval leaves, and having 8 or more leaf bones, also there is no hair on the leaf surface. (Waycott et al., 2004) state that Halophila ovalis found along the western Indo-Pacific to Australia.

\section{Seagrass Cover}

The average percentage of seagrass cover at

\begin{tabular}{|c|c|c|c|c|c|}
\hline \multirow{2}{*}{ Loc } & \multicolumn{3}{|c|}{ Transect (\%) } & \multirow{2}{*}{$\begin{array}{c}\text { Av Cover } \\
(\%)\end{array}$} & \multirow{2}{*}{$\begin{array}{c}\text { Standard of } \\
\text { Deviation }\end{array}$} \\
\hline & 1 & 2 & 3 & & \\
\hline $\mathrm{Pj}$ & 39 & 41 & 18 & 32.6 & Moderate \\
\hline $\mathrm{PP}$ & 31 & 45 & 39 & 38 & Moderate \\
\hline
\end{tabular}
Jhembangan and Pasir Putih beaches are 32.6\% and $38 \%$ (Table 1).

Table 1. Value of Percentage Result of Seagrass Cover

Pj: Jhembangan Beach

PP: Pasir Putih Beach 
The coverage value between 32.6-38 percent, according to 2004 Decree of the state minister for the Environment No. 20, included in moderate. The low percentage of seagrass cover, according to Argadi (2003) may be caused by the low morphology of the seagrass species itself.

\section{Seagrass Distribution}

The distribution value of the seagrass on the Jhembangan and Pasir Putih beaches acquired based on the morisita index. The distribution of the seagrass on the Jhembangan beach is grouped with a value of 0.43 and 0.3 , and the distribution of the seagrass on the Pasir Putih beaches is clustered with a value of 1 and 0.78 for the Enhalus acoroides and Thalassia hemprichii, while the distribution of the seagrass is clustered with a value of 1 and 0.78 for the Halophila ovalis it is uniform with a value of -29.59 (table 2).

Table 2. The distribution value of seagrass at Jhembangan and Pasir Putih beach

\begin{tabular}{cccc}
\hline Loc & Type & Total $(\mathbf{\Sigma x})$ & $\begin{array}{c}\text { Morisita index } \\
(\mathbf{I p})\end{array}$ \\
\hline \multirow{2}{*}{ PJ } & $E a$ & 1,217 & 0.47 \\
& $T h$ & 1,910 & 0.3 \\
PP & $E a$ & 35 & 1 \\
& $T h$ & 7,449 & 0.78 \\
& $H o$ & 26 & -29.59 \\
\hline
\end{tabular}

\begin{tabular}{ll}
\multicolumn{2}{l}{ Information: } \\
Ea $\quad$ Enhalus acoroides \\
Th & : Thalassia hemprichii \\
Ho & : Halophila ovalis \\
PJ & : Jhembangan Beach \\
PP & : Pasir Putih Beach
\end{tabular}

The distribution pattern is uniform if Ip $<0$, the distribution pattern is random if $\mathrm{Ip}=0$, and the distribution pattern is clustered if Ip $>0$, depending on the Morisita Index (Metananda et al., 2016). Thalassia hemprichii grows on sand and rock fractures. The substrate area of sand and rocky sand is the largest in the Intertidal Zone at the study site. In addition, Thalassia hemprichii and Enhalus acoroides has a favorable morphological structure in accelerating its distribution. The standardized delivery reflects the citizens in the society where heavy competition occurs (Michael, 1994).

4. Correlation of Seagrass with abiotic Factors

Table 3 shows the association between seagrass and abiotic variables, including temperature, salinity, $\mathrm{pH}$ and DO.

The findings of the correlation analysis indicate a very good correlation between the most influential abiotic variables, i.e. $\mathrm{pH}$ with Thalassia hemprichii 0.923 (Table. 3), and are directly proportional or positive. That acidity can be used as a parameter that can assess a water's productivity, according to Nurilahi (2013). Dissolved oxygen (DO) with Enhalus acoroides 0.986 (Table. 3) is the most influential abiotic element on the beach of Pasir Putih. The content of DO in waters is closely linked to the degree of contamination and the amount of organic matter in the water (Salmin, 2005).

\section{Importance Value Index (Ivi)}

Thalassia hemprichii were found to have the highest Importance Value Index values at both locations 113.71 (Table 4) at Jhambangan beach 187.68 (Table 5), while at Pasir Putih beach 187.68 (Table 5) based on the results of the measurement of the significance value index in the two locations.

Table 3. Correlation values of seagrass with abiotic factors of temperature, salinity, $\mathrm{pH}$ and DO

\begin{tabular}{llcccc}
\hline \multirow{2}{*}{ Loc } & \multirow{2}{*}{ Type } & \multicolumn{4}{c}{ Parameter } \\
\cline { 3 - 6 } & & Temperature & Salinity & DO & pH \\
\hline \multirow{2}{*}{ PJ } & $E a$ & $\mathbf{0 . 8 3 2}$ & -0.531 & -0.597 & -0.338 \\
& $T h$ & 0.593 & $\mathbf{0 . 8 2 0}$ & $\mathbf{0 . 7 7 2}$ & $\mathbf{0 . 9 2 3}$ \\
PP & $E a$ & -0.868 & -0.936 & $\mathbf{0 . 9 8 6}$ & -0.904 \\
& $T h$ & $\mathbf{0 . 8 8 0}$ & $\mathbf{0 . 9 4 4}$ & -0.981 & $\mathbf{0 . 9 1 5}$ \\
& $H o$ & 0.850 & 0.755 & -0.327 & 0.806 \\
\hline
\end{tabular}

Information: Ea (Enhalus acoroides); Th (Thalassia hemprichii); Ho (Halophila ovalis); PJ (Jhembangan Beach); PP (Pasir Putih Beach) 
Table 4. Importance Value Index (IVI) of seagrass at Jhembangan beach

\begin{tabular}{cccccc}
\hline Species & $\mathbf{K i}$ & $\mathbf{K r}$ & $\mathbf{F i}$ & $\mathbf{F r}$ & IVI \\
\hline$E a$ & 40.56 & 38.91 & 0.9 & 47.36 & 86.28 \\
$T h$ & 63.66 & 61.08 & 1 & 52.63 & 113.71 \\
\multicolumn{3}{c}{ Total } & & & $\mathbf{2 0 0}$ \\
\hline
\end{tabular}

Information:

Ea : Enhalus acoroides

Th : Thalassia hemprichii

The Significance Value Index of the two research locations in Jhembangan beach was found to be 113.71 percent for Thalassia hemprichii and Enhallus acoroides of 86.28 percent (Tables 4 and 5). Whereas the highest value index for Thalassia hemprichii was 187.68 at Pasir Putih Beach and the IVI value for the Enhallus acoroides was 9.31 percent, the Halophila ovalis was 3 percent (table 5). The is an important value index (IVI), to describe the role of a type of vegetation in an ecosystem (Fachrul, 2007).

Table 5. Importance Value Index (IVI) of seagrass at Pasir Putih beach

\begin{tabular}{cccccc}
\hline Species & $\mathbf{K i}$ & $\mathbf{K r}$ & $\mathbf{F i}$ & $\mathbf{F r}$ & $\mathbf{I V I}$ \\
\hline$E a$ & 1.16 & 0.46 & 0.1 & 8.84 & 9.31 \\
$\mathrm{Th}$ & 248.3 & 99.18 & 1 & 88.49 & 187.68 \\
$\mathrm{Ho}$ & 0.86 & 0.34 & 0.03 & 2.65 & 3 \\
\multicolumn{3}{c}{ Total } & & & 200 \\
\hline
\end{tabular}

Information:

$\begin{array}{ll}\text { Ea } & : \text { Enhalus acoroides } \\ \text { Th } & : \text { Thalassia hemprichii } \\ \text { Ho } & \text { : Halophila ovalis }\end{array}$

Thalassia hemripchii has the highest IVI value compared to other seagrass populations. Meanwhile, on the Pasir Putih beach of the Enhalus acoroides and Halophila ovalis were the lowest IVI value was (table 5). The value index is influenced by the elevated density and its relative frequency, according to Marwanto (2017), Patty and Rifai (2013) added Density is a structure and community factor that is useful for estimating the development of seagrass. Thalassia hemprichii species dominated the two research locations according to the results.

The low density of the Halophila ovalis and Enhalus acoroides in Pasir Putih Beach is partially due to the inadequacy of the substrate found in the white sand beach itself. According to Minerva et al. (2014) besides being affected by variables from the seagrass itself, Halophila ovalis typically lives around the reef. Enhalus acoroides grows on sandy and muddy substrates in addition, the distribution of Enhalus acoroides is also influenced by its morphological structure, but Enhalus acoroides has shorter rhizomes than Thalassia hemprichii, so that horizontal growth is less than optimal, so that the distribution is not as wide as Thalassia hemprichii. Two locations have different environmental conditions. Jhembangan beach coast is more accessible because it faces the road directly, while Pasir Putih beach has mangrove forests that retain sediments from the land (Kiswara, 2004).

Thalassia hemprichii has the highest value of the relative frequency of all seagrass species found in the Jhembangan and Pasir Putih Beach. According to Bratakusuma et al. (2013) the Thalassia hemrichii on coarse sand substrates may form a single population, in mixed vegetation with distribution of $25 \mathrm{~m}$ long, Thalassia hemprichii also often dominates and may grow on sand, mud, and coral fragments as a substrate.

\section{Conclusion}

There were 3 types of seagrasses, namely: Enhalus acoroides, Thalassia hemprichii, and Halophila ovalis. The results of the calculation of seagrass cover in both research locations showed moderate seagrass cover conditions with an average value of $32.6 \%-38 \%$. For the distribution of seagrass on the Jhembangan beach, it is classified as clustered distribution with values of 0.47 and 0.3 , while in the pasir putih beach the distribution is clustered for Enhalus acoroides and Thalassia hemprichii species, with values of 1 and 0.078, Halophila ovalis species includes a uniform distribution with a value of -29.59 . The results of the correlation analysis of abiotic factors in seagrass in Jhembangan Beach that most influence is $\mathrm{pH}$ and salinity for seagrass species Thalassia hemprichii, Pasir Putih 
Beach the most influential abiotic factors for salinity for species Thalassia hemrichii and DO for species Enhalus acoroides. The research location for the seagrass species, Thalassia hemprichii, has the greatest influence on other seagrass communities that occupy both locations, Jhembangan beach and Pasir Putih.

\section{Acknowledgment}

The author would like to thank to LP2M for providing this study with facilities and funds.

\section{References}

Argadi, G. (2003). Struktur Komunitas Lamun di Perairan Pagerungan, Jawa Timur. IPB (Bogor Agicultural University). http://repository.ipb.ac.id /handle/123456789/24458

Baransano, H. K., \& Mangimbulude, J. C. (2011). Eksploitasi dan Konservasi Sumberdaya Hayati Laut dan Pesisir di Indonesia. JURNAL BIOLOGI PAPUA, 3(1), 39-45. https://doi.org/10.31957/jbp.547

Bratakusuma, N., Sahami, F. M., \& Nursinar, S. (2013). Komposisi Jenis, Kerapatan dan Tingkat Kemerataan Lamun di Desa Otiola Kecamatan Ponelo Kepulauan Kabupaten Gorontalo Utara. Jurnal Ilmiah Perikanan Dan Kelautan, 1(3), 139-146. https://doi.org/10.37905/.v1i3.1233

Brower, J. E., Zar, J. H., \& Ende, C. von. (1998). Field and Laboratory Methods for General Ecology (4th ed). WCB McGraw-Hill.

Cabaço, S., Machás, R., Vieira, V., \& Santos, R. (2008). Impacts of Urban Wastewater Discharge on Seagrass Meadows (Zostera noltii). Estuarine, Coastal and Shelf Science, 78(1), 113. https://doi.org/10.1016/j.ecss. 200 7.11.005

Fachrul, M. F. (2007). Metode Sampling Bioekologi (1st ed.). Bumi Aksara.

Hernawan, U. E., Sjafrie, N. D. M., Supriyadi, I. H., Suyarso, S., Iswari, M. Y., Anggraini, K., \& Rahmat, R. (2017). Status Padang Lamun Indonesia
2017. Pusat Penelitian OseanografLIPI.

Kiswara, W. (2004). Kondisi Padang Lamun (Seagrass) Di Perairan Teluk Banten, Tahun 1998-2001. Pusat Penelitian Oseanografi-LIPI.

Marwanto, M. (2017). Kondisi Ekosistem Padang Lamun di Perairan Desa Mantang Baru Kecamatan Mantang Kabupaten Bintan Provinsi Kepulauan Riau [Skripsi, Universitas Maritim Raja Ali Haji.]. https://jurnal.umrah.ac.id/archives/80 49

Menteri Negara Lingkungan Hidup, 200 § Keputusan Menteri Negara Lingkungan Hidup Nomor 200 Tahun 2004 Kriteria baku kerusakan dan pedoman penentuan status Padang Lamun (2004).

Metananda, A. A., Zuhud, E. A. M., \& Hikmat, A. (2016). Populasi, Sebaran dan Asosiasi Kepuh (Sterculia foetida L.) Di Kabupaten Sumbawa Nusa Tenggara Barat. Media Konservasi, 20(3), 277-287. https://doi.org/10. 29244/medkon.20.3.\%p

Michael, P. (1994). Metode ekologi untuk penyidikan ladang dan laboratorium. UI-Press.

Minerva, A., Purwanti, F., \& Suryanto, A. (2014). Analisis Hubungan Keberadaan dan Kelimpahan Lamun dengan Kualitas Air di Pulau Karimunjawa, Jepara. Management of Aquatic Resources Journal (MAQUARES), 3(3), 88-94. https://doi.org/10.14710/marj.v3i3.66 57

Nurilahi, D. (2013). Kondisi Umum Ekosistem Padang lamun Di Desa Batu Berdaun Kecamatan Singkep Kabupaten Lingga [Skripsi]. Universitas Maritim Raja Ali.

Nybakken, N., \& Willard, J. (1992). Marine Biology: An Ecological Approach = Biologi laut: Suatu pendekatan ekologis. Penerjemah Muhammad Eidman (Universitas Indonesia). Gramedia Pustaka Utama. 
Patty, S. I., \& Rifai, H. (2013). Community Structure of Seagrass Meadows In Mantehage Island Waters, North Sulawesi. Jurnal Ilmiah Platax, 1(4), 177-186. https://doi.org/10.35800/jip. 1.4.2013.3699

Salmin, S. (2005). Oksigen Terlarut (DO) dan Kebutuhan Oksigen Biologi (BOD) sebagai Salah Satu Indikator untuk Menentukan Kualitas Perairan. Oseana, $\quad X X X(3), \quad 21-26$. http://oseanografi.lipi.go.id/dokumen/ oseana_xxx(3)21-26.pdf
Sjafrie, N. D. M., Hernawan, U. E., Prayudha, B., Supriyadi, I. H., Iswari, M. Y., Rahmat, R., Anggraini, K., Rahmawati, S., \& Suyarso, S. (2018). Status Padang Lamun Indonesia 2018 Ver.02. Pusat Penelitian Oseanograf LIPI.

Waycott, M., Mcmahon, K., Mellors, J., Calladine, A., \& Kleine, D. (2004). A Guide to Tropical Seagrasses of the Indo-West Pacific. James Cook University. 